\title{
PENGARUH KETERSEDIAAN KALIUM TANAH TERHADAP RESIDU TEH KOMPOS KULIT PISANG PADA BAWANG MERAH
}

\section{THE EFFECT OF SOIL POTASSIUM AVAILABILITY ON THE RESIDUES OF BANANA PEEL COMPOS TEA IN ONION}

\author{
Raudha Anggraini Tarigan \\ *Program Studi Agroteknologi, Fakultas Pertania, Universitas Medan Area \\ Jalan Kolam Nomor 1 Medan Estate \\ Korespondensi : anggataritarigan@gmail.com
}

\begin{abstract}
ABSTRAK
Tidak semua unsur hara yang terdapat dalam tanah dapat diserap oleh tanaman, sehingga dimungkinkan terdapat sisa unsur hara di dalam tanah yang disebut dengan residu. Penelitian ini dilaksanakan di Rumah Plastik Kebun Percobaan Ngijo, Karangploso, Malang. Penelitian dilaksanakan pada bulan Maret 2016 sampai Juni 2016. Penelitian ini menggunakan Rancangan Acak Lengkap (RAL) dengan 4 perlakuan dan 3 ulangan. Hasil penelitian menunjukkan pengaruh pada residu teh kompos kulit pisang dengan dosis $125 \%$ Teh $\mathrm{Kompos}$ dan $25 \% \mathrm{KCl}$ dan dengan aplikasi kalium humat terhadap berat basah umbi. Sementara itu, peningkatan K tertinggi terdapat pada residu $125 \%$ Teh Kompos dan $25 \% \mathrm{KCl}$ dengan peningkatan $56,90 \%$ jika dibandingkan dengan kontrol.
\end{abstract}

Kata kunci: Residu teh kompos, Kalium, Bawang Merah

\begin{abstract}
Not all nutrients found in the soil can be absorbed by plants, so it is possible that there are nutrient residues in the soil called residues. This research was conducted at the Ngijo Experimental Garden Plastic House, Karangploso, Malang. The study was conducted from March 2016 to June 2016. This study used a completely randomized design with 4 treatments and 3 replications. The results showed that there was a significant effect of banana peel compost tea residue with the application of potassium humate on the $125 \%$ residue of compost tea and $25 \% \mathrm{KCl}$ on fresh weight. Meanwhile, the highest $\mathrm{K}$ increase was found in the residue of $125 \%$ compost tea and $25 \% \mathrm{KCl}$ with an increase of $56.90 \%$ when compared to the control.
\end{abstract}

Key words: Residue of compost tea, Potassium, Onion 


\section{PENDAHULUAN}

Kemandirian dan ketahanan
pangan merupakan dua kompenen
penting ditengah pandemi Covid-19 yang dapat mempengaruhi perdagangan internasional. Terutama pada komoditas hortikultura yaitu pada tanaman bawang merah. Pentingnya tanaman bawang merah karena masyarakat Indonesia selalu menggunakannya sebagai bahan utama untuk memasak makanan seharihari. Berdasarkan data statistik Tahun 2020 Provinsi Sumatera mengalami peningkatan produksi Bawang merah dari 16.103 ton (2017) menjadi 16.337 ton (2018) yang menunjukkan peningkatan produktivitas tidak optimal meskipun adanya peningkatan luas area panen. Hal ini dikarenakan beberapa faktor diantaranya adalah kurang tepat dalam pengelolaan budidaya salah satunya dikarenakan pengelolaan budidaya yang kurang tepat terutama dalam aplikasi pupuk organik dan anorganik.

Teh kompos merupakan ekstrak yang berbahan dasar air, yang disusun dari berbagai macam kompos. Teh kompos dapat mempengaruhi sifat biologi, fisika dan kimia (Scheuerell dan Mahaffee, 2002 dalam Pant et al., 2012). Hasil penelitian Aprilio (2016) menunjukkan pengaruh yang signifikan terhadap aplikasi teh kompos kulit pisang pada parameter $\mathrm{pH}, \mathrm{C}$-organik, ketersediaan $\mathrm{K}$, tinggi tanaman, jumlah daun, jumlah umbi, berat kering umbi dan serapan $\mathrm{K}$ umbi bawang merah. Ketersediaan $\mathrm{K}$ tertinggi terdapat pada dosis $150 \% \mathrm{KCl}$ yaitu sebesar 0,92 cmol kg-1, sedangkan serapan $\mathrm{K}$ terbesar pada umbi bawang merah juga terdapat pada dosis $150 \%$ yaitu sebesar 209,66 mg tanaman ${ }^{-1}$.

Sutedjo, Kartasapoetra dan Sastroadmodjo (1991) menyatakan, bahwa tidak semua unsur hara yang terdapat dalam tanah dapat diserap oleh tanaman, sehingga dimungkinkan terdapat sisa unsur hara di dalam tanah yang disebut dengan residu. Residu unsur hara dalam tanah dapat dimanfaatkan kembali untuk musim tanam selanjutnya. Oleh karena itu, tujuan dari penelitian ini adalah untuk mengetahui ketersediaan unsur hara $\mathrm{K}$ terhadap pertumbuhan bawang merah.

\section{BAHAN DAN METODE}

Penelitian ini dilaksanakan di Rumah Plastik Kebun Percobaan Ngijo, Karangploso, Malang. Penelitian dilaksanakan pada bulan Maret 2016 sampai Juni 2016. Tanah yang digunakan dalam penelitian adalah tanah pasca penanaman bawang merah dengan perlakuan aplikasi teh kompos kulit pisang. Bibit tanaman bawang merah (Allium cepa L.) yang digunakan adalah varietas Tuk-tuk Filipina.

Residu pupuk teh kompos kulit pisang sesuai dengan dosis yang telah ditentukan oleh Aprilio (2016). Dosis rekomendasi pemupukan berdasarkan Dierolf, Fairhurst dan Mutert (2001) yaitu $\mathrm{N}$ sebanyak $150 \mathrm{~kg} \mathrm{ha}^{-1}, \mathrm{P} 120 \mathrm{~kg}$ $\mathrm{kg} \mathrm{ha}^{-1}$, dan $\mathrm{S}$ sebanyak $20 \mathrm{~kg} \mathrm{~kg} \mathrm{ha-1}$. Aplikasi asam humat dilakukan pada waktu 1 minggu sebelum tanam dengan cara disiramkan pada tanah dalam polibag yang terlebih dahulu diencerkan dengan air. Aplikasi asam humat diberikan sebanyak $20,73 \mathrm{ml} \mathrm{polibag}^{-1}$ 
dengan dosis rekomendasi Siagian (2014) yaitu $0,4 \%$.

Panen dilakukan pada umur 85

HST dengan kriteria panen, 60-70\% dari seluruh perlakuan. Berat basah didapatkan dengan cara kering angin selama 1 hari. Untuk pengamatan pertumbuhan tanaman dilakukan pada 14 HST, 28 HST dan 42 HST yang meliputi tinggi tanaman/panjang tanaman yang diukur dari permukaan umbi.

Penelitian ini menggunakan Rancangan Acak Lengkap (RAL) dengan 4 perlakuan dan 3 ulangan, sebagai berikut:

$\mathrm{A} 0=$ control

A1 $=$ Residu Teh Kompos 150\%

$\mathrm{A} 2=$ Residu teh kompos $125 \%+\mathrm{KCl}$ $25 \%$

$\mathrm{A} 3=$ Residu teh kompos $50 \%+\mathrm{KCl}$ $100 \%$

A4 = Residu pupuk $\mathrm{KCl} 150 \%$

Analisis ragam dilakukan untuk mengetahui pengaruh pada setiap perlakuan terhadap parameter yang diukur dengan uji F 5\%

\section{HASIL DAN PEMBAHASAN \\ 1. pH Tanah}

Reaksi tanah mempunyai peran penting terhadap proses penyediaan unsur hara. Aplikasi kalium humat pada residu teh kompos kulit pisang menunjukkan peningkatan dan termasuk kriteria netral jika dibandingkan dengan perlakuan A0 (kontrol) yang disajikan pada Tabel 1 .

Tabel 1. Pengaruh residu teh kompos kulit pisang dengan aplikasi kalium humat pada $\mathrm{pH}$ tanah

\begin{tabular}{|c|c|}
\hline Perlakuan & $\mathrm{pH}$ \\
\hline A0 & 6.5 \\
\hline A1 & 6.7 \\
\hline A2 & 6.6 \\
\hline A3 & 6.6 \\
\hline A4 & 6.6 \\
\hline
\end{tabular}

dikarenakan aplikasi kalium humat yang dapat meningkatkan $\mathrm{pH}$ tanah melalui pertukaran kation dan adanya residu teh kompos kulit pisang. Hasil penelitian tersebut didukung oleh Pan et al. (2012) yang menunjukkan bahwa teh kompos yang berasal dari pupuk kandang ayam dan kompos limbah juga dapat menetralkan $\mathrm{pH}$ yang bekisar antara 7,3 - 7,9. Sebagai tambahan aplikasi kalium humat sebanyak $100 \mathrm{~kg}$ dan $70 \mathrm{~kg}$ P2O5 ha $^{-1}$ secara signifikan memberikan pengaruh pada EC, pH dan Effective Cation Exchange Capacity (ECEC), nilai maximum untuk total karbon terdapat pada perlakuan $100 \mathrm{~kg} \mathrm{KH} \mathrm{ha}^{-1}$ (Shujrah et al.2010).

\section{Ketersediaan $\mathbf{K}$}

Kalium berperan penting dalam aktivitas enzim dan dapat meningkatkan translokasi asimilasi. Defisiensi kalium dapat mengurangi akumulasi berat kering dan dapat mempengaruhi jaringan tanaman pada bagian asimilasi (Zhao et al., 2001; Bolandnazar, Mollavali, Tabatabaei, 2012) Kalium dapat dibedakan menjadi 3 bentuk, yaitu: (a) Kalium tersedia, merupakan kalium yang dapat segera diserap oleh tanaman, dalam bentuk $\mathrm{K}^{+}$. (b) Kalium tidak tersedia, merupakan kalium yang berada di dalam tanah dalam bentuk senyawa organik atau anorganik yang tidak larut, dan tidak tersedia sampai 
senyawa organik dimineralisasi atau senyawa anorganik dilapuk. (c) Kalium lambat tersedia, 5 merupakan kalium yang ketersediannya diantara tersedia dan tidak tersedia, (termasuk kalium yang dapat difiksasi dan dilepaskan secara bergantian oleh mineral liat tipe 2:1, terutama Illit) (Handayanto, 1998).

Tabel 2. Pengaruh Residu Teh Kompos Kulit Pisang dengan Penambahan Kalium Humat Terhadap Ketersediaan Kalium

\begin{tabular}{lllll}
\hline & \multicolumn{4}{c}{ Ketersediaan K } \\
\cline { 2 - 5 } Perlakuan & \multicolumn{4}{c}{--------ppm------ } \\
\cline { 2 - 5 } & 0 & 28 & 42 & 85 \\
& HST & HST & HST & HST \\
\hline A0 & $0.32^{\mathrm{R}}$ & 1.96 & 3.66 & 1.16 \\
& & ST & ST & ST \\
A1 & $0.42^{\mathrm{S}}$ & 3.06 & 5.09 & 1.75 \\
& & ST & ST & ST \\
A2 & 0.47 & 2.44 & 6.26 & 1.82 \\
& S & ST & ST & ST \\
A3 & 0.40 & 2.58 & 4.79 & 1.45 \\
& S & ST & ST & ST \\
A4 & 0.43 & 2.68 & 4.26 & 1.60 \\
& S & ST & ST & ST \\
\hline
\end{tabular}

Hasil penelitian menunjukkan bahwasanya aplikasi kalium humat pada residu teh kompos kulit pisang menunjukkan pengaruh yang signifikan dan mengalami peningkatan sebesar 50, 86\% pada A2, sementara pada A4 hanya meningkat sebsar 37,93\% (Tabel 2). Peningkatan ketersediaan $\mathrm{K}^{+}$pada residu teh kompos kulit pisang disebabkan aplikasi asam humat yang dapat mengurangi fiksasi kalium dikarenakan adanya mineralisasi $\mathrm{K}$. Hasil penelitian Siddiqui et al. (2011) menunjukkan, bahwa aplikasi teh kompos dengan dosis $1 \mathrm{~L}(50 \%)$ dan N, $\mathrm{P}, \mathrm{K}$ dengan dosis $50,25,25 \mathrm{~kg} \mathrm{ha}^{-1}$ ,secara signifikan dapat meningkatkan $\mathrm{N}, \mathrm{P}$ dan K pada tanaman pak choi. Hal ini dikarenakan, bahwa penggunaan kompos, teh kompos atau pupuk hayati dapat meningkatkan kandungan unsur hara makro. Di lain sisi terdapat hubungan positif antara teh kompos dan mikroorganisme yang dapat meningkatkan luas permukaan akar sehingga dapat mempengaruhi proses fisiologis tanaman.

\section{Tinggi tanaman dan Bobot basah Bawang Merah}

Pengamatan tinggi tanaman dilakukan selama masa vegetatif, pengukuran tinggi tanaman dilakukan untuk mengetahui perbandingan pertumbuhan antar tanaman akibat aplikasi asam humat pada residu teh kompos. Pengaruh aplikasi kalium humat tidak signifikan pada setiap perlakuan dan waktu pengamatan baik pada kontrol maupun dengan perlakuan, akan tetapi dapat meningkatkan pertumbuhan tinggi tanaman. Hasil penelitian ini sama dengan hasil penelitian Suwardi, Dewi dan Hermawan (2009) yang menunjukkan, bahwa perlakuan asam humat dan zeolit tidak signifikan terhadap tinggi tanaman padi. Kalium memiliki peran penting pada kualitas umbi, hal ini dikarenakan kalium berperan untuk pembentukan dan transfer karbohidrat tanaman, fotosintesis serta sintesis protein (Handayanto, 1998). Putra (2014) menambahkan bahwa kalium memliki peran penting dalam meningkatkan kualitas umbi yang berupa bobot umbi, 
jumlah umbi, dan besar umbi. Pengaruh residu teh kompos dengan aplikasi asam humat pada perlakuan A2, A3 dan A4 menunjukkan hasil yang signifikan terhadap parameter berat basah tanaman jika dibandingkan dengan perlakuan A0 (kontrol).

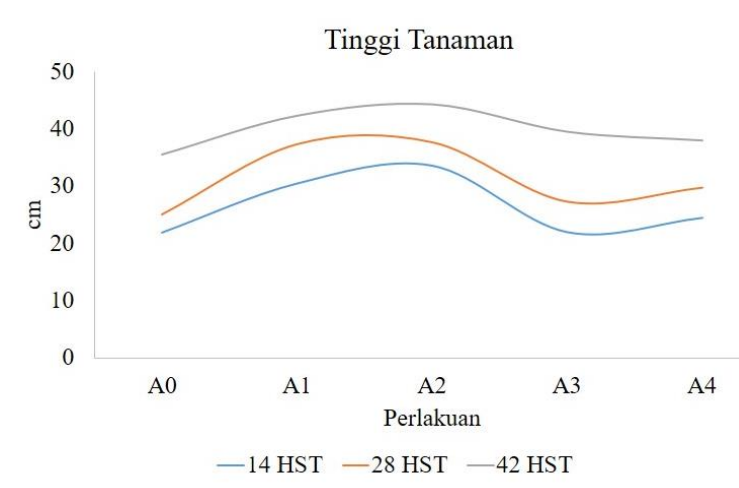

Gambar 1. Pengarh Residu Teh Kompos Kulit Pisang Dengan Penambahan Kalium Humat Terhadap Tinggi Tanaman Bawang Merah.

Asam humat dapat mempengaruhi pertumbuhan tanaman baik secara langsung maupun tidak langsung pada berat basah tanaman. Hal ini didukung oleh Canellas et al. (2008) menambahkan bahwa asam humat dapat menstimulasi pertumbuhan akar dan berpengaruh pada morfologi akar melalui eksudasi bahan organik yang dapat meningkatkan serapan hara dan pertumbuhan serta hasil tanaman. Selain itu, peningkatan produksi pada bawang merah dikarenakan unsur hara kalium yang berperan sebagai proses fisiologi sehingga dapat meningkatkan perkembangan jaringan tanaman melalui sintesis gula sederhana, pati, serta translokasi karbohidrat dan sintesis protein (Yaseen et al., 2010).

\section{KESIMPULAN}

Residu teh kompos kulit pisang $125 \%+\mathrm{KCl} 25 \%$ dengan penambahan kalium humat dapat meningkatkan ketersediaan kalium sebesar 56,90\% jika dibandingkan dengan kontrol. Serta juga dapat meningkatkan berat basak umbi.

\section{UCAPAN TERIMAKASIH}

Ucapan terimakasih disampaikan kepada pihak yang membantu baik secara material dan non material.

\section{DAFTAR PUSTAKA}

Pant, A. P., T.J.K. Radovich, N.V. Hue, dan R.E. Paull, 2012. Biochemical Properties of Compost Tea Associated with Compost Quality and Efeects on Pak Choi Growth. Science Hort., 148: $138-146$.

Aprilio, A. 2016. Uji Efektifitas Aplikasi Pupuk Tehh Kompos Kulit Pisang Untuk Meningkatkan Ketersediaan dan Serapan Kalium Serta Produksi Umbi Bawang Merah (Allium cepa L.) pada Alfisols. Skripsi. Universitas Brawijaya. Malang.

Sutedjo, M.M., A. G., Kartasapoetra dan Sastroadmodjo, R.D. S. 1991. Mikro Biologi Tanah. PT. Rineka Cipta. Jakarta. P. 87

Dierolf, T., T. Fairhust dan E. Mutert. 2001. Soil Fertility Kit a Tool Kit fir Acid, Up Land Soil Fertility Management in Soil Southeast Asia.

Shujrah, A.A., K.Y. Mohd, A. Hussin, R. Othman, dan O.H. Ahmed. 2010. Impact of potassium humate on selected chemical properties of an Acidic soil. 19 World Congress of Soil Science, 
Soil Solution for a Changing World.

Zhao, D., D.M. Oosterhuis, C.W. Bednarz. 2001. Influence of potassium deficiency on photosynthesis, chlorophyll content and chloroplast ultrastructure of cotton plants. Photosynthetica, 39: 103-109.

Bolandnazar, S., M. Mollavali, dan S.J. Tabatabaei, 2012. Influence of $\mathrm{NH}_{4} \mathrm{NO}_{3}$ and $\mathrm{K}_{2} \mathrm{SO}_{4}$ on Qualitaitive Characteristics of Onion. Sci Horticultura, 136: 2428.

Handayanto, E. 1998. Pengelolaan Kesuburan Tanah. Fakultas Pertanian. Universitas Brawijaya, Malang. P 27-38.

Siddiqui, Y., T.J., Islam, Y., S. Naidu, dan Meon. 2011. The Conjunctive Use of Compost Tea and Inorganic Fertiliser on The Growth, Yield and Terpenoid Content of Catella asiatica (L.) Urban. Science Horticultura, 130: 289-295.

Suwardi, E.M. Dewi dan B.A. Hermawan. 2009. Aplikasi Zeolit Sebagai Karier Asam Humat Untuk Peningkatan Produksi Tanaman Pangan. Journal of Indonesia Zeolites, 8 (1): 14116723.

Putra, M. J. N. F. I. A. 2014. Aplikasi Kompos Batang Pisang Untuk Meningkatkan Ketersediaan dan Serapan Kalium Serta Produksi Umbi Bawang Merah (Allium cepa L.) Pada Inceptisols Dau. Skripsi. Universitas Brawijaya. Malang.

Canellas, L.P., L.R.L. Teixeira-Junior, L.B. Dobbss, C.A. Silva, L.O. Medici, D.B. Zandonadi dan A.R. Facanha. 2008. Humic Acids Cross Interactions With Root
And Organic Acids. Ann. Appl. Biol., 153: 157-166.

Yaseen, A.A., A.M. Habib, Sahar, M. Zaghloul, dan S.M. Khaled. 2010. Effect of different sources of potassium fertilizer on growth, yield, and chemical composition of Calendula officinalis. J. American Sci., 6(12): 1044-1048 